\title{
Extreme poverty, violence and inclusive education in Haiti: Student performance analysis from the multifactorial approach
}

\author{
Pobreza extrema, violencia y \\ educación inclusiva en Haití: \\ Análisis del desempeño estudiantil \\ desde el enfoque multifactorial
}

DOI: http://dx.doi.org/10.17981/cultedusoc.12.1.2021.02

Recibido: 4 de marzo de 2020. Aceptado: 19 de agosto de 2020. Publicado: 8 de noviembre de 2020

Moïse Lindor

El Colegio de Tlaxcala, A.C. Tlaxcala (México)

moiselindor76@gmail.com

Marilú Carro-Suárez (1)

El Colegio de Tlaxcala, A.C. Tlaxcala (México)

maryluzcarsua@gmail.com

Para citar este artículo:

Lindor, M. \& Carro-Suárez, M. (2021). Extreme poverty, violence and inclusive education in Haiti: Student performance analysis from the multifactorial approach. Cultura, Educación y Sociedad, 12(1), 19-36. DOI: http://dx.doi.org/10.17981/cultedusoc.12.1.2021.02

\section{Abstract}

The objective of this work is to analyze the impact of violence, crime, kidnapping and extreme poverty on the academic performance and mental health of high school and undergraduate students in public schools and colleges located in Port-au-Prince (Haiti). It is a qualitative research of a deductive type and a semistructured interview to collect the data and draw the pertinent conclusions. The results show a proportion of undergraduate students in very difficult socioeconomic situations, and with fear of being kidnapped when going to school, due to violent acts. Likewise, high school students have expressed their fear of being violated, which causes various psychological disorders. It was concluded that poverty and violent events harm inclusive and continuous education, school performance, collective well-being and the tranquility of students, and the general population.

Keywords: Violence; education; extreme poverty; school dropout; perception of fear

\section{Resumen}

El objetivo de este trabajo es analizar el impacto de la violencia, el crimen, los secuestros y la pobreza extrema en el rendimiento académico y la salud mental de los alumnos de bachillerato y de licenciatura de las escuelas y facultades públicas ubicadas en Puerto Príncipe (Haití). Es una investigación cualitativa de tipo deductivo y entrevista semi-estructurada para recolectar los datos y sacar las conclusiones pertinentes. Los resultados evidencian una proporción de estudiantes de licenciatura en situaciones socioeconómicas muy difíciles, y con miedo a ser secuestrados al momento de ir a la escuela, por los actos violentos. Asimismo, los alumnos de bachillerato han expresado su temor a ser violentados, lo que provoca diversos trastornos psicológicos. Se concluyó que la pobreza y los sucesos violentos perjudican la educación inclusiva y continua, el rendimiento escolar, el bienestar colectivo y la tranquilidad de los estudiantes, y la población en general.

Palabras clave: Violencia; educativa; pobreza extrema; deserción escolar; percepción del miedo 


\section{INTRODUCTION}

Violence has taken millions of deaths annually. The disastrous and permanent consequences of violence and extreme poverty are the perfect combination for the progressive destruction of individuals. It is a fact the prevalence of violence has grown, and at the same time becomes one of the causes of homicides and femicides. It appears that poverty and unemployment cause juvenile delinquency in Haiti to some extent. Several scholars agree that recent years are marked by violent events and repetitive social conflicts in Latin America and the Caribbean.

It is important to note that young people are exposed to various violent situations and the phenomenon of gangage in the cities. Frequent forms of violence against children and adolescents consist of physical punishment, psychological punishment, deprivation of affection, deprivation of affection, bullying, begging, child labor, induction into drug abuse, sexual abuse, pornography, child soldier enlistment, gang induction and crime. Another worrying aspect is the violence exerted by adolescents and young people themselves in the form of gangage (Garmendia, 2011).

Today, violent crimes affect various aspects of modern life, such as the quality of life and health levels of individuals, as well as the economic, political, and social situation of countries. However, measures taken to attack violence should not be interpreted merely as a problem of illegal behavior and law-strengthening, but also as a phenomenon closely associated with economic, social, and cultural development peoples. It is very true that unemployment and precariousness can increase the risk of widespread violence in a society. In this sense:

Unemployment creates poverty and poverty, in turn, creates economic and social insecurity.It is a cyclical process that is concatenated, but feasible to break. There are alternative solutions, which imply willingness and vigorous action by the public authorities to take economic measures appropriate to our reality, to boost national production and to courageously address inequality of opportunity and economic discrimination. However, as long as crime, insecurity and violence are addressed with palliative measures, the objective of guaranteeing the right to security for the people will not be achieved (Sánchez, 2016, pp. 95).

According to Anceschi (2009) violence is a subjective concept of complex definition, since it can acquire various types of meanings depending on the point of view from which it is analyzed... It is "the violation of the integrity of the person", which "is usually exercised when the physical force or threat of its use intervenes, but also when acted in a sequence that causes helplessness in the other" (Vidal, 2008, p. 17). While the World Health Organization (WHO, 2013) declares that violence contributes to countless health problems for women and children in Latin America and the Caribbean, including physical injuries; mental health disorders such as anxiety, depression, suicidal ideation and psychoactive substance use, as well as reproductive health problems such as unwanted pregnancies, abortions and sexually transmitted infections. 
Therefore, violence is considered a form of exercise of power that facilitates domination, oppression or supremacy for those who exercise it, and a position of subjugation or substraint of the sufferer. In all its manifestations, it becomes a public health problem involving all countries and, although it does not constitute a disease in the traditional sense of its understanding, where the biological etiological element plays as a rule a fundamental role; in the social sense it is a health problem and an important factor of psychosocial risk, due to the magnitude of the damage, the disability and death it causes, with multiple and diversified consequences at the social, psychological and biological levels (González, Pardo \& Izquierdo, 2017). While Espín, Valladares, Abad, Presno \& Gener (2008) said that:

Violence is a human health problem, which in addition to being a of risk for many diseases and health problems, is determined by multiple systemic interactions of a biological, psychological and social nature, which interweave in a network of interactions contained in human activity. There are different types: the self-inflicted, the interpersonal and the collective, which relate with the nature of the violent act, which can be physical, sexual, psychic and carelessness or deprivation (p. 5).

Therefore, the citizen dissatisfaction manifested through recurrent claims and protests causes social disadvantages and encourages conflicts in communities, mainly socially vulnerable people who suffer more from violent events in the social, economic and educational spheres. In this sense, the school dropout and/or partial academic involvement of many children, adolescents and university students has been reported due to insecurity and armed conflict in the region specifically in Haiti, apart from the extreme poverty that generates, to some extent, socio-educational lag and illiteracy.

Educational inequality and social violence have stuck strongly to the future of Haitian children and young people; this clearly explains the significant rate of educational delay and school dropout recorded in recent years. Let us recall that Social violence means any act with social impact that affects the physical, psychic or relational integrity of a person or a collective, such acts being carried out by a subject or by the community itself (Castillero, 2017).

Similarly, the capacity of governments to create the necessary means of survival to ensure the common well-being and guarantee the human rights of each inhabitant is questioned. Finally, the abductions of students and other citizens provoke an atmosphere of panic and fear that can harm social peace. It is also necessary to investigate the effects of these violent events on the social and academic performance of students in the capital. Because education is one of the factors that most influences the advancement and progress of people and societies. In addition to providing knowledge, education enriches the culture, spirit, values and everything that characterizes us as human beings. In short, education contributes to fairer, more productive and equitable societies. It is a social good that makes human beings freer (Narro, Martuscelli \& Barzana, 2012). 


\title{
Methodology
}

This research is qualitative in which the inductive method and semi-structured interview are used to be able to argue the current socioeconomic situation, the educational policies implemented by the Haitian authorities, as well as to collect the opinions, perceptions and beliefs of the students. The work focuses on analyzing the extreme poverty, violence and fear that influence students' poor school performance. To arrive at this critical but constructive analysis, deductive-inductive reasoning es considered important to find and obtain new insights into the problem. The deductive method is a form of reasoning that starts from a universal truth to draw particular conclusions. In scientific research, this method has a dual function to cover the unknown consequences of known principles (López, 2001).

Thus, the deductive method opposes induction. According to Dávila (2006), deductive and inductive reasoning is very useful for research. The deduction allows establishing a link between theory and observation and allows deducing from theory the phenomena under observation. Induction involves accumulating isolated knowledge and information. If the premises of deductive reasoning are true, so will the conclusion. This reasoning makes it possible to organize the premises in syllogisms that provide decisive evidence for the validity of a conclusion; usually said in incomprehensive situation "Deduced", however, deductive reasoning has limitations. It is necessary to start with true premises to reach valid conclusions. Therefore:

\begin{abstract}
Although the inductive method is the reasoning by which, from the analysis of singular facts, it is intended to come to the law. In other words, it is based on the analysis of concrete examples that are broken down into parts and then come to a conclusion. This is similar to the analytical method described above. In short, scientific research represents the synthesis of studies and research throughout which general conclusions are established on certain knowledge (Maya, 2014, p. 15).
\end{abstract}

\section{Sample description}

For analysis, undergraduate students of private faculties and high school students are considered in situations of social vulnerability. Working with all 100 students (60 undergraduate and 40 high school students) who began in the first academic cycle of 2019-2020. It is important to note that all respondents study in schools and public faculties, between November 2019 and January 2020 in Port-au-Prince.

\section{Survey design and Technical}

Specifically for the study was used a semi-structured questionnaire with 15 open, semiopen and closed questions to evaluate the variables chosen to see their relationship to student dropout risk, school performance, perception of fear and violence, as well as for data collection and analysis interpretation. Considering Hansen's procedure of forming a subsample with some of the participants who have not responded to the questionnaire for them. Then do everything you can, no matter what it takes, until you get your answer. 
This is considered representative of the whole group and therefore extends to it (García, 2003). López-Roldan \& Fachelli (2015) state:

In the semi-directed interview (semidirective, semi-structured or also called in depth, and which would include biographical methods) the subject is organized and broken down into areas or sub-items whose order and how to introduce them through questions or suggestions are not necessarily fixed rigidly, there is great flexibility but also a requirement to collect that information that is raised from the research with the help of an interview script (p. 10). ${ }^{1}$

Taking into consideration a number of 112,554 high school students (Bacc I and II) and 31,000 students from the Haitian State University for the 2019-2020 academic cycle, the T-Student technique was used to take the sample considering the ecuation (1), where the population of $N=143,554$ students from both groups:

$$
n=\frac{N Z^{2} P Q}{d^{2(N-1)+Z^{2} P Q}}
$$

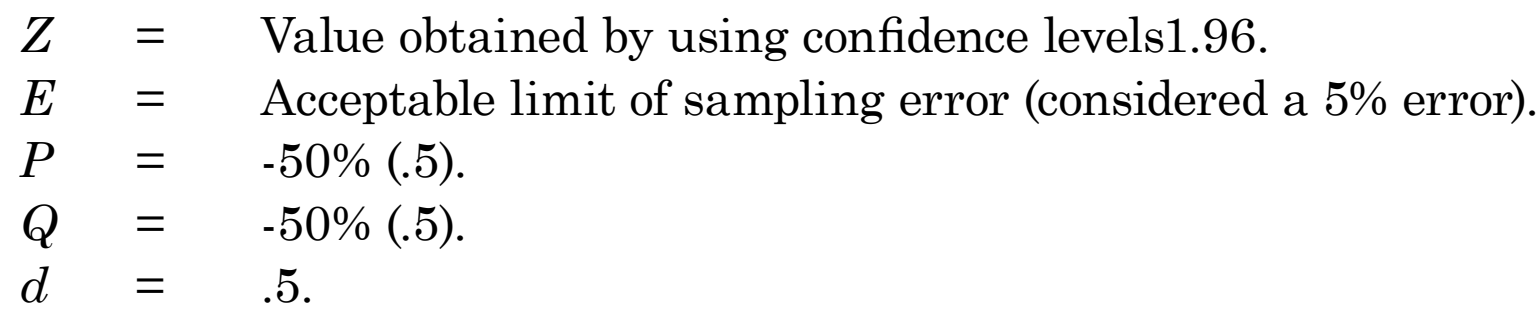

Finally, it should be remembered that Student's $t$ was initially designed to examine the differences between two independent and small samples that have normal distribution and homogeneity in their variances (Sánchez, 2015). Thus, 15 to 20 minutes have been dedicated for each student of both categories and similar situations to be able to respond voluntarily to the instrument's reagents examining the problem from the multifactorial approach in psychology to get the potential benefits of diversification where several elements are involved. Excel software has been used for the processing of data, which allows to achieve the objectives and findings of the research presented through the graphs and tables.

\section{LITERATURE REVIEW}

\section{Violence, unemployment and poverty}

The Republic of Haiti remains one of the poorest countries in the world despite its attractive tourist sites, beaches, tropical climate, gastronomy and cultural diversity, among other things that have allowed it to be recognized as the pearl of the Caribbean in the past, but the rest is history. For several decades the population has been living in conditions of

\footnotetext{
${ }^{1}$ In this sense, the questions do not are direct (clear, common to interviewer and interviewee, on issues that the interviewees known) but indirect, act on stimuli where the real sense of question and the answer want to go beyond appearance, in the line of techniques (such as the Rorschach test), it's about discovering a reality that doesn't, formulated or not known to the interviewee himself (such as the Rorschach test) it's about discovering a reality that doesn't formulated or not known to the interviewee himself.
} 
vulnerability and misery. Difficult socioeconomic situations damage hope to a better life, resulting in the mass displacement of young Haitians abroad, briefly, and the brain drain. "Haiti's case is critical, 83 percent of people with university education reside outside the country" (Gamboa, 2012).

Those young preparations who have not managed to leave their place of origin are already part of the unemployed with diplomas. This juncture has also contributed to the creation of various criminal gangs operating in the capital and adjoining cities; poverty is therefore a violation of human rights because its consequences are disastrous for human dignity and integrity. One agrees with the statement United Nations Organization (UN, 2016) that "high poverty rates are often found in small, fragile and conflict-affected countries" (par, 8). In this case, this phenomenon is not only reduced in per capita income or sustainable means and goods, but the problem goes further considering the slow destruction of the individual in chronic poverty due to disaggregation and inequalities socio-economic impacts, as well as their impact on their descendants.

In this way, the UN (2016) declares that poverty goes beyond a lack of income and resources to ensure sustainable livelihoods. Poverty is a human rights problem with different manifestations of poverty include hunger, malnutrition, lack of decent housing, and limited access to other basic services such as education or health. Today, more than 780 million people live below the international poverty line. More than eleven percent of the world's population lives in extreme poverty and must strive to meet the most basic needs, such as health, education and access to water and sanitation, among other things. There are 122 women aged 25 to 34 living in poverty for every 100 men in the same age group and more than 160 million children are at risk of continuing to live in extreme poverty by 2030 .

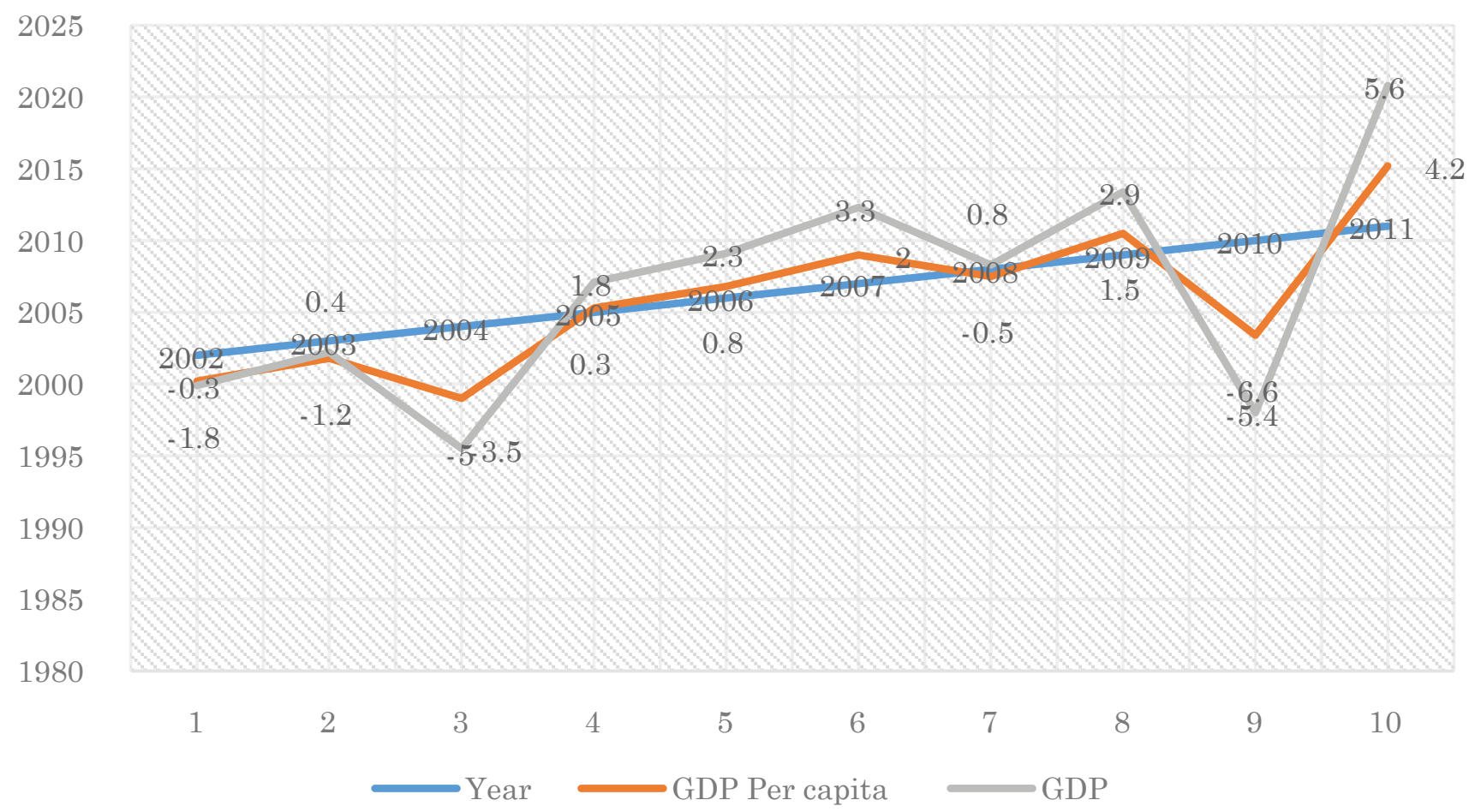

Figure 1. Annual rates of change in GDP and GDP per capita, 2002-2011 (\%). Source: Own elaboration with data of the ECLAC (2013). 
The sad reality is that Haiti is not only among the world's poor countries but is considered to be the least advanced in the Latin American and Caribbean region with nearly $80 \%$ of its population in extreme poverty due to the decline in GDP per capita. According to Economic Commission for Latin America and the Caribbean (ECLAC, 2013), in the last ten years, economic growth has been weak (1.8\% per annum on average) and unstable, with falls due to socio-political events (2004) or natural disasters (2004, 2008 and 2010) (Figure 1). This, coupled with the dynamism of population growth, has led in the same period to an average decline in GDP per capita (-0.9\% per year) which is the continuation of a long-term trend since 1987.

Consequently, the natural disasters and unemployment of half the population are indicators of extreme poverty in Haiti. Likewise, corruption in all three powers, the inability of rulers to meet the real needs of all urban and rural inhabitants facilitate the increase of social conflicts, administrative mediocrity, mistrust institutional and current ungovernability. ECLAC (2013) supports the above reflection when it presents figures for the economic activity of the working-age population and the unemployment rate in the country. ECLAC it notes,

Low rates of economic activity of the working-age population (10 years and older) because the country was still in a pre-demographic phase. Women's activity rates are even lower (40.8\% compared to $55.3 \%$ of men). On the other hand, very high open unemployment among young people (more than 30\% among those aged 20-24) and in the urban environment (33\% in the Metropolitan Area of Port-au-Prince). Taking into account the inactive people available for work, it has been estimated that the enlarged unemployment rate was especially high among women (48.7\% against $32.3 \%$ among men) and young people (almost $60 \%$ of people between the ages of 20 and 24). Inactive women available to work are mostly among the housewives of whom $41.2 \%$ would prefer to be able to work part-time (ECLAC, 2013, p. 10).

Obviously, this situation becomes a palpable human rights problem by resuming the social and economic rights that any person of age and capacity to carry out a decent economic activity to meet the expectations of their homes. In turn, certain individuals took it as pretexts to eternize violence and crime in Haitian society; such a terrifying attitude forces parents to keep their infants at home for preventive safety measures. When these fundamental rights are not automatically respected the integrity of the individual and that of his/her family members, it is attacked. Thus, the effects of extreme poverty and unproductiveness lead directly to indelible misery, hunger, illiteracy and certain chronic psychosomatic problems.

Unemployment as a result of unproductive economic activity definitely leads to a major step in non-attendance or dropout and chronic poverty in Haiti (Table 1). With regard to school attendance, a high percentage of Latin American students show rates of chronic absenteeism are analyzed. Students who are missing $10 \%$ or more from the school year incur chronic absenteeism and are at educational risk. In consequence, Latin American and Caribbean, between 16 and 43\% of third graders miss school two or more days a month, ranging from 13 to $39 \%$ for sixth graders. Considering the high levels of chronic absenteeism in the region, it is necessary to develop educational and 
social policies that help improve school attendance and increase the time available for learning (United Nations Educational, Scientific and Cultural Organization, UNESCO, 2016).

TABLE 1.

Haiti: main indicators of the employment system, population aged 10 years and over, 2007(\%)

\begin{tabular}{|c|c|c|c|c|c|c|}
\hline \multirow[b]{2}{*}{ Indicators } & \multicolumn{3}{|c|}{ Residence zone } & \multicolumn{2}{|c|}{ Sex } & \multirow[b]{2}{*}{ Total } \\
\hline & $\begin{array}{l}\text { Port -au- Prince } \\
\text { Metropolitan Area }\end{array}$ & $\begin{array}{l}\text { Other } \\
\text { cities }\end{array}$ & $\begin{array}{l}\text { Rural } \\
\text { areas }\end{array}$ & Men & Woman & \\
\hline Activity rate & 48,1 & 43,0 & 49,0 & 55,3 & 40,8 & 47,7 \\
\hline Unemployment rate & 33,3 & 20,1 & 9,4 & 14,9 & 19,2 & 16,8 \\
\hline Expanded unemployment rate & 52,1 & 46,5 & 34,2 & 32,3 & 48,7 & 40,6 \\
\hline Informality rate & 88,4 & 76,0 & 43,2 & 39,6 & 78,2 & 57,1 \\
\hline
\end{tabular}

Source: own elaboration with database of the Institute Haitian of Statistics and Informatics (IHSI, 2010).

Data from Table 1 show that $52.1 \%$ of broad unemployment in the metropolitan area (Port-au-Prince), $46.5 \%$ in other cities; $34.2 \%$ in rural areas. It is important to remember that women and people in rural communities are more prone to extreme poverty and unemployment in Haiti. The data from Table 1 warrant this comment when it shows that $48.7 \%$ women versus $32.3 \%$ men are unemployed, a total of $40.6 \%$ of the population aged 10 and over. It should be noted that the formula (2) for calculating the expanded unemployment rate is:

$$
\frac{\text { Unemployed Open }+ \text { Inactive available }}{\text { Active population }+ \text { Inactive available }} \times 1
$$

However,

The following has been commented: Several of the countries that currently have high levels of unemployment are countries where formal wage relations had already reached very high levels of expansion in the past. The career paths and expectations of the unemployed population in these countries can hardly be absorbed by the urban informal sector even in the conditions of severe restraint that currently characterize the labor market (Educational Trends Information System in Latin America, 2005).

For his part, Sánchez (2016) states that lack of employment is the undeniable expression of an economic and social situation that undermines the foundations of a fundamental right of the individual: access to a dignified life, for him and his family. One of the consequences of unemployment, in addition to economic and family problems, is that, in the long term, it produces hopelessness, demotivates the individual, and decreases their selfesteem, generating emotional insecurity and lack of perspective on work in the immediate future. 
It must understood that unemployment and violence alone do not prevent children and young people from attending school, inconsistent education policies, gratuitousness, obligation, and almost non-existent educational secularism contribute to school dropout, work child and juvenile delinquency. The right to free education as a fundamental right is not respected; on the contrary private schools because they are higher in quantity, considerably increase school costs. This becomes an educational inequity resulting from tangible social injustice and the violation of inherent rights by resuming international agreements to the right to education. As UNESCO (2018) points out:

The right to education is an indispensable human right for the exercise of other human rights. Quality education aims at the complete development of human beings. This teaching is one of the most powerful tools to improve the social status of marginalized children and adults, lift them out of poverty and integrate them into society because if all adults in the world had completed secondary education, the number of could be reduced by more than $50 \%$. Quality education narrows the gender gap for girls and women as it has been shown that each school year reduces the likelihood of child mortality from 5 to 10\% (par. 3-6).

The postulate of that international institution seems more interesting when it add the for this human right to be effective, there needs to be equal opportunities, universal access to education and quality criteria of compulsory application, which can be monitored. However, it can be concluded that free, quality education and access to adequate school spaces and resources is a human right that all states should guarantee all their people by eliminating inequalities and disparities in education and ensuring the lives and property of students in times of social conflict.

Recalling that the right to education is established in two ways, through international normative instruments and through political commitment by governments. There is a strong international framework for protecting the right to education, and the States that subscribe to it undertake to respect, protect and comply with this right. Here are some elements proposed by UNESCO (2018) that constitute the right to education:

Free, compulsory and universal primary education. B) Secondary education, including technical and vocational training, which is widely available, accessible to all and progressively free.

C) Higher education accessible to all, based on individual capacity, and progressively free. D) Basic education for those who have not completed their education. E) Vocational training opportunities. F) A homogeneous quality in education using minimum criteria. G) Quality training and teaching materials for teachers. H) A system of scholarships and material conditions suitable for teaching staff. I) Freedom of choice (par. 9-17).

It is believe that these elements are indispensable to promote respect for human rights also. Some authors agree to use the term "educability "to study the right conditions so that all students have the same opportunities and rights to a quality and equitable education. Therefore, the concept of educability becomes a key notion when it comes to identify what are the social conditions that make it possible for all children and adolescents to access the necessary resources to receive a quality education. Educability today is an agenda for education: a new hybrid pedagogical method in which different teaching models and constructive resources converge will be the engine in the work of re-appointing the school (López, 2003; Feijoó \& Corbetta, 2004; Schenone \& Narodowski, 2017). 
Likewise, man is educated because he is able to communicate and to communicate requires the implementation of the opportune mechanisms of openness towards others, which determines the capacity of choice when it comes to facing the various options presented. Optionality is permanent because situations that arise in daily life require it and cannot find adequate response from the purely practical. Moreover, public school resources are highly criticized compared to private schools with greater infrastructure, what is the largest evidence of social, economic and educational discrimination? In any case, school resources such as the school's infrastructure, facilities and basic services are important both for the well-being and safety of children and for establishing a minimum operating base that encourages learning. However, its distribution is uneven depending on the socio-economic level.

Similarly, education policies are the tools of the authorities to bring about changes in school systems to improve students' learning opportunities and ensure the right to education for all in the region. Policies require nurturing empirical evidence and conceptual models to help understand reality in each country, as well as the nature and magnitude of the educational challenges they face (UNESCO, 2016). If there is no good governance, there can also be consistent public policies that meet social and educational expectations.

In addition, the right to education for all is supported by certain international agreements signed by some ministers and authorities in the region. For Muñoz (2014) the purpose of education is to build useful knowledge to dignify the lives of all people. At this point, education can make the difference between life and death (for this reason, considering education only as a social or cultural right is to deny it its full dimension). Perhaps this is also a point at which to beginn talking about the human right to learning, since teaching to learn is perhaps the most urgent pedagogical defeat that must promote. This will be the future of the struggles in the century to come, centered on overcoming inequality, exclusion and violence.

\section{Perception of fear, mental disorders, and violence}

The consequences of violence and abductions on the mental health of victims are varied and multiple. People who have experienced some form of violence do not recover easily; rather, psychosomatic symptoms may be present for life. According to Plazaola \& Ruíz (2004), physical injuries are the most visible consequence of violence, but not the only one. Chronic health pains and problems can be caused by injuries, fear and stress caused by abuse. Some of the most common psychological consequences are post-traumatic stress syndrome, depression, anguish, low selfesteem, social isolation, guilt, phobias or panic states, loss of sexual appetite or even rejection of sex.

Violence being one of the death factors in the world causes a perception of fear, anxiety, nervousness and other emotional problems. This is a dangerous situation where several young students feel insecure and helpless by the violent events, criminality, rape and kidnappings that influence their calm and human dignity that can lead to suicide. 
For Robles (2014), increased crime, the emergence of new forms of more violent crime, insecurity on the streets, impunity for crime and poor involvement of police corporations have increased the nonconformity of society to the point that the issue of public criminal insecurity is one of the main issues of social debate.

Added to this, violence has become a public health and national security issue (Sarabia, 2018). It can be said that the perception of fear in the streets and the stresses that live this collective significantly affect their school performance and mental health, at the same time make clear the challenge that the authorities must face to establish and guarantee the proper social peace and learning in Haitian society.

Precisely, street crime is the source of the perception of fear and insecurity that impacts social cohesiveness and causes revictimization, so these acts are not easily denounced for fear of reprisals. According to United Nations Development Programme (UNDP, 2013) street crime refers to acts motivated by profit, sorry for such as theft and small theft, which often occur in public places and may in some cases involve threats of violence, beatings or injuries against victims. They pass more intensely in urban environments and are generally not reported.

Likewise, the main strategies to prevent disputes from leading to conflict or preventing conflicts from re-emergeing are preventive diplomacy and disarmament. Preventive diplomacy refers to measures taken to prevent disputes from arising or led to conflict, and to limit the spread of disputes when they occur. This may be mediation, conciliation or negotiation. In the new millennium, peacekeepers were deployed in Liberia, Cote d'Ivoire, Darfur, South Sudan, Haiti, and Mali (UN, 2013). Therefore, by 2030, 167 million children will live in extreme poverty if something is not done to improve access to health care and education (UN, 2013).

In considering that extreme poverty is linked to inequalities, violence and marginalization, it is urgent to eradicate it to ensure social and educational rights and to foster a free and peaceful environment that leads to reducing and avoiding mental problems. Now, it is a pending challenge for the Haitian rulers.

\section{RESULTS}

Data show that $70 \%$ of undergraduate students are in a very difficult socioeconomic situation but the percentage of women (36\%) slightly superior to men (34\%). While 33\% of girls versus $27 \%$ of high school boys are in the same situation. Similarly, $15 \%$ of undergraduate students and 10\% of high school students are identified in difficult socioeconomic status (Figure 2). It is important to note that the Haitian population is young; more than $50 \%$ are under the age of $23 ; 34 \%$, less than 15 years; and $4.5 \%$, over 65 , and girls and women attend school less frequently for domestic work. Based on criteria such as relative workload, access to education and separation from their parents, there are some 286,000 children in Haiti aged 5 to 14 who are considered child domestic workers. These children usually move on to third parties in the hope of improving their opportunities, but they are vulnerable to exploitation. 


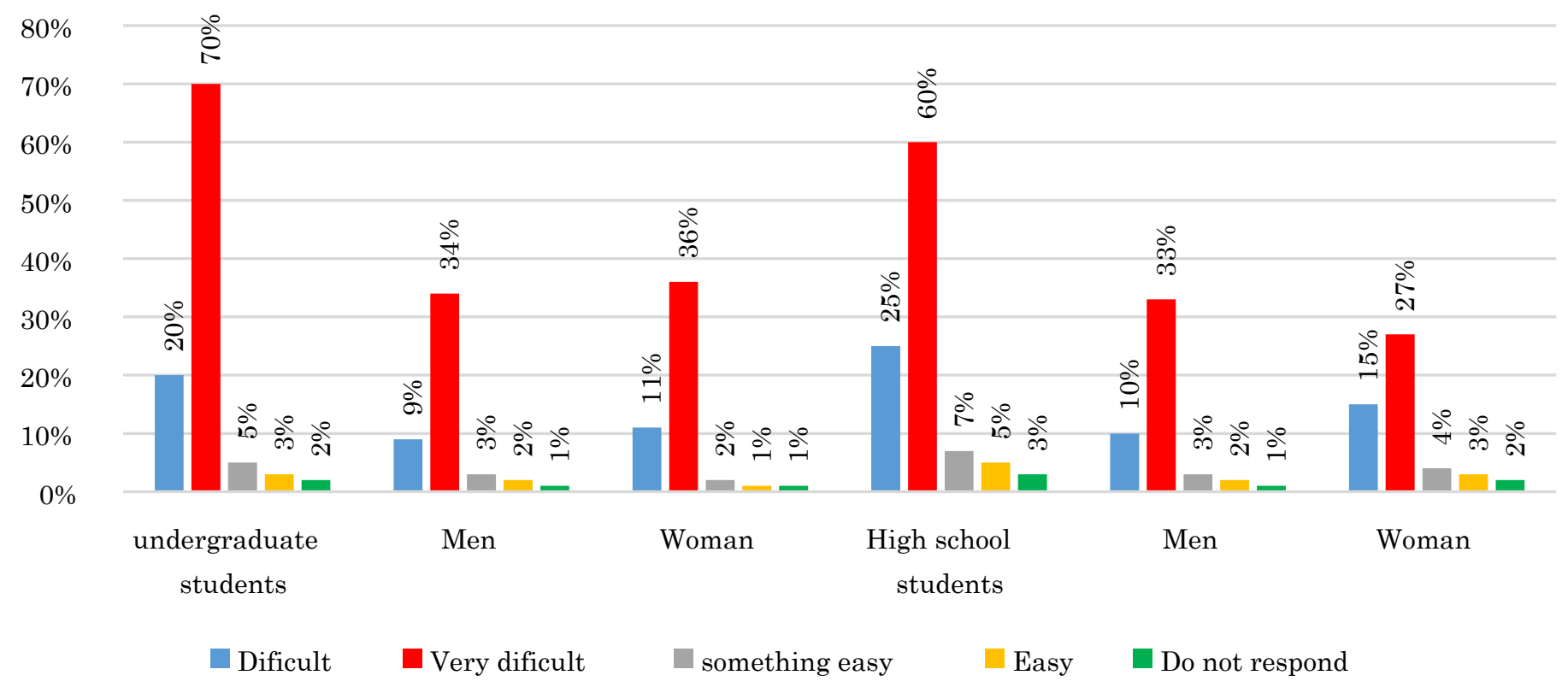

Figure 2. Socioeconomic status of undergraduate and high school students, Port-au- Prince Source: Own elaboration, fieldwork 2019.

According to the United Nations Children's Fund (UNICEF, 2010):

Pre-earthquake estimates indicate that 50,000 children were in residential care. Some of them had one of their parents, others had a father and a mother, and others had neither a father nor a mother. In reality, children were interned in these institutions for complex socio-economic reasons (p. 13).

[...] Less than half of school-age children attended school. 20 percent of children attended public schools, which accounted for only 8 percent of all schools. There were 22,000 schools in all over the country. Following the 2010 earthquake, more than 2.5 million children suffered interruptions in their studies. There were 4,992 affected schools, of which 3,978 were damaged or destroyed. There were 55,793 civil servants affected education sector (p. 14).

It should be noted that due to the deaths recorded in the 2010 earthquake, many children were orphaned or under the protection of third parties. On the other hand, many schools have also recorded an alarming drop in the number of enrollments in a context where only four out of ten children attended school before the earthquake. In addition, more than 3,978 damaged schools were registered or destroyed. UNICEF (2010) noted also that, in Léogane, one of the hardest-hit areas, less than 50 per cent of children who attended school before the earthquake have returned to classrooms. Teachers are also lacking, as many of them are displaced people and lack the means to continue with his work.

As for the perception of fear caused by recent violent events and abductions in the education sector, $96 \%$ of undergraduate students or $78 \%$ of women and $18 \%$ of men are afraid of being abducted at the time of going to school, while $2 \%$ of both sexes respectively report that they fear violent acts. Similarly, $98 \%$ of high school students have expressed their fear of being victims of some kind of attack at the time of going to school, i.e. $82 \%$ of girls and $15 \%$ of boys (Figure 3 ). 


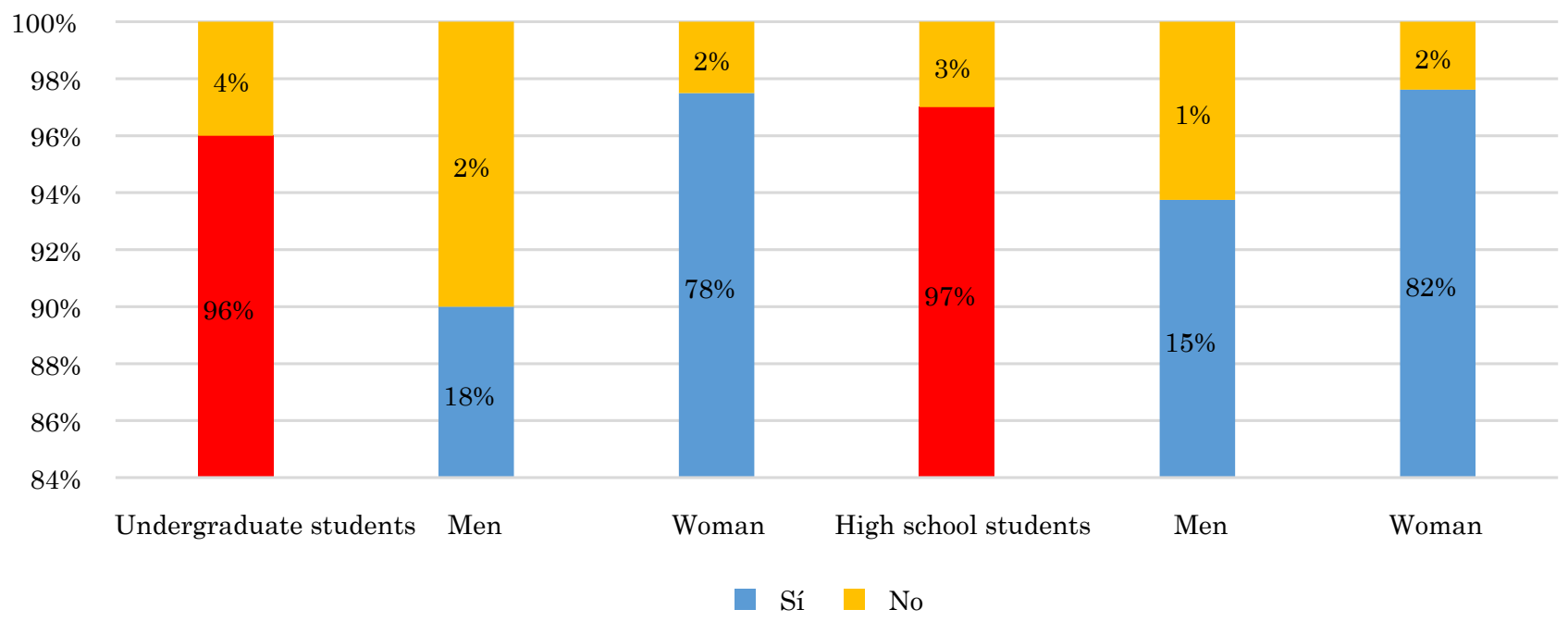

Figure 3. Perception of fear caused by violence and kidnapping in undergraduate and high school students, Port-au-Prince

Source: Own elaboration, fieldwork 2019.

Data in Figure 4 show that 90 percent of female students in both groups are more vulnerable to some form of violence or abduction than are male students (70 percent), especially students who attend school on night shifts. As a result, $65 \%$ of females versus $57 \%$ of males perform poorly in school due to acute stress disorder and anxiety (females $81 \%$ and males $79 \%$ ). It is important to remember that most areas do not have electricity or few hours of light consumption, which influences the increase of kidnappings, robberies and sexual violations in the population; many homes still use old lamps and candles as electric energy, and students use them to study, as well as firewood as fuel for cooking and other domestic activities. Here one can see how students from both groups are more prone to the negative effects of violence, kidnappings and other criminal acts in Haitian society. It is known with certainty that the rate of armed conflict and murder is higher for men than for women.

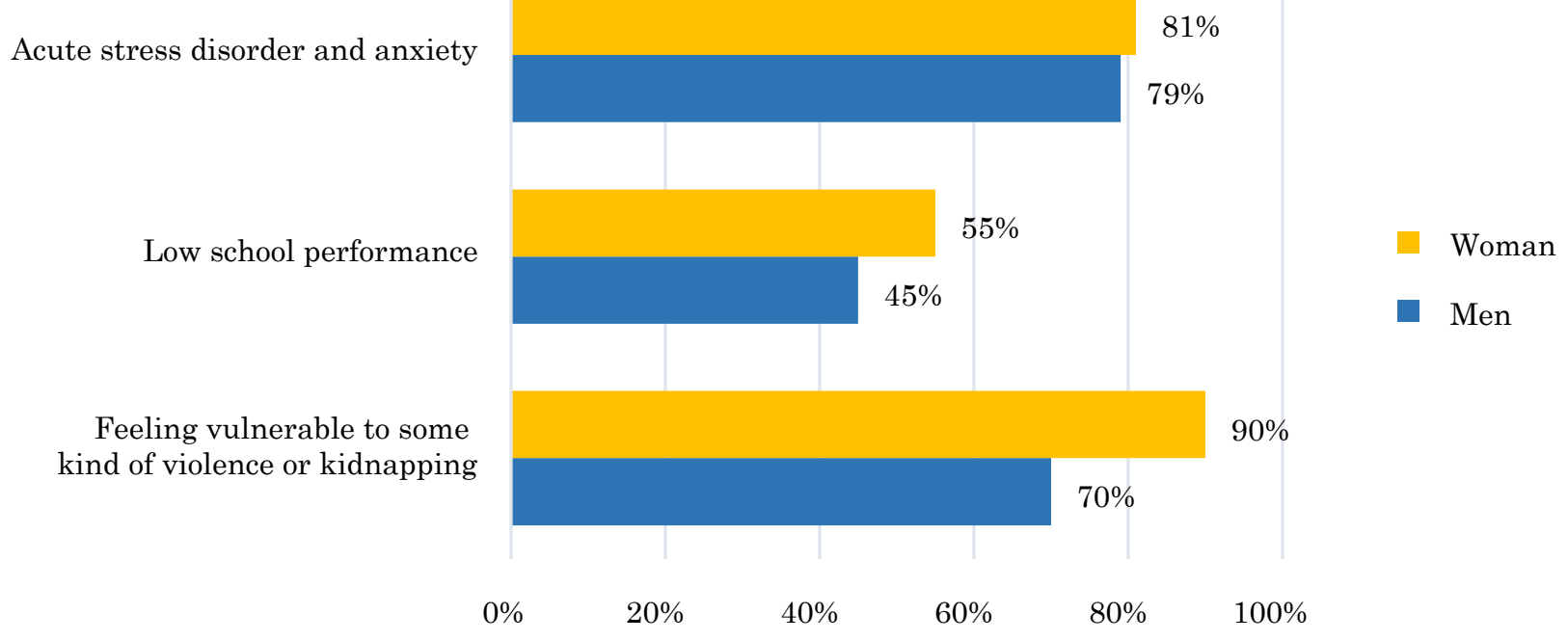

Figure 4. Perception of violence, kidnapping, school performance and psychological disorders in students, Port-au-Prince Source: own elaboration, fieldwork 2019. 


\section{DiscUssion}

In contrast to the research findings, students can be seen as not benefiting from the rights to inclusive education either to a life free from violence. The Survey on Living Conditions in Haiti 2001-ECVH (Haitian Institute of Statistics and Informatics-HISI, 2001) mentions a proportion of $76 \%$ of extreme poor people, findings from this research show that poverty and insecurity have increased in Haiti especially in the youth population. Therefore, qualified young people who fail to overcome these great social and educational problems prefer to leave the country, others more vulnerable stayed, at the cost of their own lives and their future.

By looking at students' responses to socioeconomic conditions, violent events and their psychological aftermath, at this critical time of the Covid-19 pandemic it will be more difficult for parents to send their children to school because the state does not really have a national free and compulsory education program, and armed gangs continue to control the country's neighborhoods. Here can confirm that remittances have been and remain Haiti's essential economic source. But will they be enough to solve all the difficulties? Do all households receive remittances in the capital? However, the state must respond efficiently to collective expectations, including the socioeconomic and educational demands of the population.

On the other hand, this does not mean that there are no or unaware of efforts that have been made to remedy the situation, but it would be nice to start by combating corruption, impunity, injustice and disparities as well as social discord. In any case, education is fundamental to local sustainable development, autonomy and independence. Indeed, education allows emancipation and probably the guarantee of a better future depending on the infrastructures, quality educational programs and public development policies implemented by governments to prevent brain drain.

Education is necessary in every way. To achieve better levels of social welfare and economic growth; to level economic and social inequalities; to promote people's social mobility; to access better levels of employment; to raise the cultural conditions of the population; to expand young people's opportunities; to invigorate civic and lay values that strengthen the relationships of societies; for democratic advancement and strengthening of the rule of law; boosting science, technology and innovation (Narro et al., 2012).

Similarly, it is inadmissible that access to education is so limited and discriminated against in society. Bearing in mind that all are equal and must be treated with equity, respect and dignity, which means that inclusion, social cohesion and transparency are the thermometer of a democratic state.

Socioeconomic and educational inequalities as well as chronic poverty and corruption are harmful elements for self-realization and progress in a society. Indeed, there is a cause-and-effect relationship between violent events, abductions, disparities and mental disorders caused by frightening situations in the population, for example, stress, anxiety, panic, which lead to poor academic performance and drop-out. "Those who have been victims of a violent event are at increased risk of mental disorder" (Echeburúa, 2019). The same way, to understand the phenomenon of violence can analyze the factors that influence behavior and that can increase the risk of committing or suffering violent acts. There is 
no single factor that explains why one person behaves violently and another does not. It is a complex, web of biological, social, cultural, economic, political factors. Predicting violence is no easy task, although certain conditions can help make estimates of the risk of violent behavior (Vinces, 2006).

Now, it is posible to understand the emergency and responsibility of addressing these social difficulties; set a good example for children and young people (present and future citizens) as well as foster social coexistence, educational integration, tranquility and richness in the country.

\section{Conclusions}

It can be concluded that it is necessary to understand the causes and effects of extreme poverty and unemployment to analyze the violence and abductions that significantly affect the academic performance of the university students and high schools in the capital that have interviewed. Violent events cause various educational and mental problems such as acute stress and anxiety in students from traumatic events, as well as a significant proportion of students living in constant fear.

Socio-economic conditions have a major impact on school non-attendance, premature dissent and domesticity for children. Likewise, it is necessary to improve the education system through the obligatory, gratuity, quality and equity of education that characterize the process of democratic consolidation and good governance. It is the right time to rethink education policy and public safety and enforce respect for human rights from a perspective of equality and non-discrimination. Teaching moral values and ethical principles from childhood are essential to prevent criminal acts, violence, juvenile delinquency and kidnappings in Haitian society. These misconduct can be avoided as long as parents and guardians shape and model them, and the authorities must take all necessary measures to ensure the safety of students and the entire population, but they must also ensure inclusive education, to satisfy social rights and to eliminate the practice of "child slavery" domesticity in Haiti.

Finally, the price of extreme poverty and unemployment is the anguish of heads of households to achieve all that is socially desirable for household members on their own, which also affects the completion of studies in an appropriate time. From the multifactorial approach can see that several factors are involved in school dropout and poor academic performance of students, for example, violence, kidnapping, chronic extreme poverty, perception of fear and stress. In this regard, the authorities are encouraged to implement better public policies on safety, public health and inclusive education to counteract the major problems affecting school performance and social peace in Haiti.

However, the promotion of inclusive and equitable education and a peaceful environment must be the task of all social and political actors, in order to build a more balanced, just and prosperous society. As Ortiz (2015) points out:

Education doesn't just depend on attending school and memorizing all the data provided, it's not just up to the government, it's not just about teachers or parents. Education is a joint work of public servants and society, but above all it is an act of conscience and responsibility that we must all adopt in order to achieve our development as a country and achieve a better quality of life (par. 1). 
In this sense, secular, free and compulsory education must be a reality; there is no point in continuing to use it as a political discourse to convince voters. Similarly, inclusion, security and social justice must be the priorities of all governments to ensure human rights, citizen participation and the peace of the inhabitants.

\section{REFERENCES}

Castillero, M. O. (March 8, 2017). What is social violence? In Psychology and mind. [Online]. Available: https://psicologiaymente.com/social/violencia-social\#: :text=Violencia\%20 social\%3A\%20\%C2\%BFqu\%C3\%A9\%20es\%3F,o\%20por\%20la\%20propia\%20comunidad

Dávila, N. G. (2006). Inductive and deductive reasoning within the research process in experimental and social sciences. Laurus, 12(1), 180-205. Available: https://biblat. unam.mx/es/revista/laurus

Echeburúa, E. (2019). Violence and mental disorders. A complex relationship. Neurology journal, 69(11), 69-472. https://doi.org/10.33588/rn.6911.2019424

ECLAC. (2013). Social protection systems in Latin America and the Caribbean: Haiti. [Online]. Available: https://www.cepal.org/es/publicaciones/4050-sistemas-proteccionsocial-america-latina-caribe-haiti

Educational Trends Information System in Latin America. (2005). Trends in the relationship between education and unemployment in Latin America. [Online]. Available: http://archivo.siteal.iipe.unesco.org/sites/default/files/tendencias_educacion_ desempleo.pdf

Espín, J. C., Valladares, A. M., Abad, J. C., Presno, C.\& Gener, N. (2008). Violence, a health problem. Cuban Journal of Comprehensive General Medicine, 24(4), 1-6. Available: http://scielo.sld.cu/scielo.php?script=sci_arttext\&pid=S0864-21252008000400009

Feijoó, M. \& Corbetta, S. (2004). School and poverty: educational challenges in two scenarios in Greater Buenos Aires [Argentina]. [Online]. Buenos Aires: IIPE-UNESCO. Available: https://unesdoc.unesco.org/ark:/48223/pf0000142343

Gamboa, A. (november 27, 2012). Brain drain grows in poor countries. [Online]. Availablein: https://aldianews.com/es/articles/politics/crece-fuga-de-cerebros-en-pa\%C3\%ADsespobres/30058

García, T. (2003). The questionnaire as a research/evaluation tool. [Online]. Available in: http://www.univsantana.com/sociologia/El_Cuestionario.pdf

Garmendia, L. F. (2011). Violence in Latin America. Annals of the Faculty of Medicine, 72(4), 269-276. https://oi.org/10.15381/anales.v72i4.1081

González, E. G., Pardo, M. E. \& Izquierdo, J. M. (2017). Violence as a public health problem in Venezuela: some reflections from the perspective of the citizen security professional. Medisan, 21(5), 642-648. Available: http://scielo.sld.cu/pdf/san/v21n5/ san20215.pdf

IHSI. (2001). Survey on Living Conditions in Haiti 2001. ECVH, 2001. [Online]. Available: https://catalog.ihsn.org/index.php/catalog/4320

López, N. (2003). What's new, man? [Document for discussion]. Buenos Aires: Mimeo.

López, J. L. (2001). Scientific Methods and Hypothesis. México, D.F.: Trillas. 
López-Roldan, P. \& Fachelli, S. (2015). Social research methodology Quantitative. Barcelona: Universitat Autònoma de Barcelona. Available: https://ddd.uab.cat/pub/caplli/2016/163567/metinvsoccua_a2016_cap2-3.pdf

Maya, E. (2014). Research methods and techniques. An agile proposal for presentation scientific work in the areas of architecture, urban planning and related disciplines. Ciudad de México: UNAM. Mexico.

Muñoz, V. (2014). The Human Right to Education. Sinéctica Electronic journal of education, 42(1), 1-10. Available: https://sinectica.iteso.mx/index.php/SINECTICA/article/ view/67/59

Narro, J., Martuscelli, J. \& Barzana, E. (Coord.) (2012). Ten-year plan to develop the National Education System. [Online]. México, D.F.: UNAM. Available: http://www. planeducativonacional.unam.mx

Ortiz, F. X. (january 29, 2015). The importance of education in Mexico. Practice. [Online]. Available: https://www.gestiopolis.com/la-importancia-de-la-educacion-en-mexico-ensayo/2

Robles, A. L. (2014). Fear in the streets: the main thrill of public criminal insecurity. A criminological and gender study. Journal of the Institute of Legal Sciences of Puebla, 8(34), 81-100. http://dx.doi.org/10.35487/RIUS.V8I34.2014.123

Plazaola-Castaño, J. \& Ruíz, I. (2004). Violence against women in the couple and consequences on physical and mental health. Clinical Medicine, 122(12), 461-467. https:// doi.org/10.1016/S0025-7753(04)74273-6

Sánchez, C. J. (2016). Insecurity and unemployment. Population and Development Magazine, 29(16), 94-106. Available: https://dialnet.unirioja.es/descarga/articulo/5654297. pdf

Sánchez, R. A. (2015). Student's T. Uses and abuses. Mexican cadiology magazine, 26(1), México, D.F. Available: https://www.medigraphic.com/cgi-bin/new/resumen. cgi?IDARTICULO=56921

Sarabia, S. (2018). Violence: a public health priority. Journal of Neuro-Psychiatry, 81(1), 1-8. http://dx.doi.org/https://doi.org/10.20453/rnp.v81i1.3267

Schenone, M. \& Narodowski, M. (2018). The educability in the educational agenda. A Hybrid Method. [Online]. Available: https://www.researchgate.net/publication/327189371_LA_EDUCABILIDAD_en_la_agenda_educativa_Un_Metodo_hibrido

UN. (2016). Ending poverty. [Online].Available: https://www.un.org/es/sections/issuesdepth/poverty/index.html

UN. (2013). Peace and Security. [Online]. Available: https://www.un.org/es/sections/issues-depth/peace-and-security/index.html

UN. UNDP. (2013). Human Development Report for Latin America 2013-2014. [Online]. Available: https://www.latinamerica.undp.org/content/rblac/en/home/library/human_development/informe-regionalde-desarrollo-humano2013-2014-.html

UNESCO. (october 10, 2018). What you need to know about the right to education. [Online]. Available: https://en.unesco.org/news/what-you-need-know-about-right-education 
UNESCO. (2016). Education Policies Recommendations in Latin America based on Terce. [Online]. Santiago de Chile: OREALC/UNESCO. Available: http://www. unesco.org/new/fileadmin/MULTIMEDIA/FIELD/Santiago/pdf/Education-PoliciesRecommendations.pdf

UNICEF. (2010). Children in Haiti. Achievements and perspectives six months after the Earthquake. [Online]. Available: https://www.unicef.org/Infancia_en_Haiti-_6_meses_despues.pdf

Vinces, E. (2006). Violence and mental illness. Spanish Journal of Penitentiary Health, 8(3), 95-99. Available: http://www.sanipe.es/OJS/index.php/RESP/article/view/119/279

Vidal, F. (2008). The new accelerators of remoderned violence. In: A. Garcia-Mina (Coord.), New scenarios of violence. Reflections Quotes Social Sciences I (pp. 17-46). Madrid: Universidad Pontificia Comillas de Madrid.

WHO. (2013). Global and regional estimates of violence against women: prevalence and health effects of intimate partner violence and non-partner sexual violence. Ginebra: WHO. Available: http://www.who.int/reproductivehealth/publications/violence/9789241564625/en/

Moïse Lindor, Doctor in Regional Development. Full-time Professor-Researcher. Member of Urban Affairs Association (USA). Former Director of the Center for Political and Social Studies of the Colegio de Tlaxcala, A.C. (México). Member of the National System of Researchers (SNI). https://orcid.org/0000-0002-6656-4306

Marilú Carro Suarez. El Colegio de Tlaxcala, A.C. Tlaxcala (México). https://orcid. org/0000-0002-3402-8410 